Editorial

\title{
Acknowledgment to Reviewers of Psych in 2020
}

\author{
Psych Editorial Office
}

Citation: Psych Editorial Office.

Acknowledgment to Reviewers of

Psych in 2020. Psych 2021, 3, 18.

https://doi.org/10.3390/psych3010002

Published: 26 January 2021

Publisher's Note: MDPI stays neutral with regard to jurisdictional claims in published maps and institutional affiliations.

Copyright: (c) 2021 by the author. Licensee MDPI, Basel, Switzerland. This article is an open access article distributed under the terms and conditions of the Creative Commons Attribution (CC BY) license (http://creativecommons.org/licenses /by/4.0/).

MDPI AG, St. Alban-Anlage 66, 4052 Basel, Switzerland

Peer review is the driving force of journal development, and reviewers are gatekeepers who ensure that Psych maintains its standards for the high quality of its published papers. Thanks to the cooperation of our reviewers, in 2020, the median time to first decision was 21.5 days and the median time to publication was 58 days. The editors would like to express their sincere gratitude to the following reviewers for their precious time and dedication, regardless of whether the papers were finally published:

Adina, Turcu-Stiolica

Albohn, Daniel

Andersson, Björn

Bazilinskyy, Pavlo

Carstensen, Claus H.

Charvát, Karel

Cook-Cottone, Catherine

Debeer, Dries

Dimitrov, Dimiter M.

Doebler, Philipp

Dwibedi, Nilanjana

Fairhurst, Merle T.

Farroni, Teresa

Gärtner, Anne

Hipolito, Ines

Jones, Martin

Juen, Barbara

Kalckert, Andreas

Kennair, Leif Edward Ottesen

Klichowski, Michał

Leijon, Arne

Liou, Michelle

MacAllister, William

McLaughlin, Nicole
Mestre, Jose M.

Molenaar, Dylan

Mosteller, Jill R.

Murphy, Raegan

Navarro, Raul

Paap, Muirne Caitlin Shonagh

Pinet, Svetlana

Pokropek, Artur

Ponocny, Ivo

Pritikin, Joshua

Puig-Perez, Sara

Ranger, Jochen

Roseiro, Luís

Rudaz, Myriam

Rudy, Ligtvoet

Sánchez-Rico, Marina

Slavin, Konstantin

Takahashi, Kayoko

Valor-Segura, Inmaculada

Vintila, Mona

Vitoratou, Silia

Wei, Zheng Zachory

Wirkner, Janine

$\mathrm{Xu}$, Gongjun 